\title{
EVALUATION OF GREEN MANUFACTURING IMPLEMENTATION ON REGULATION, COSTS, AND KNOWLEDGE
}

\author{
Iggy Adbaidainy ${ }^{a}$ \\ ${ }^{a}$ Fakultas Bisnis dan Ekonomika Universitas Islam Indonesia \\ Email: adbaidhainy@gmail.com ${ }^{\text {a }}$
}

ARTICLE HISTORY

Received:

10 November 2020

Revised

03 March 2021

Accepted:

07 April 2021

Online available:

06 May 2021

Keywords:

Green Manufacturing,

Regulation,

Costs,

Knowledge.

\begin{abstract}
Introduction: This study aims to analyze whether there is motivation of knowledge, regulations, and costs on the effect of the application of Green Manufacturing. Part of green manufacturing has been implemented. However, its implementation is not easy for various reasons and it has not a significant effect on the industrial world from several sectors.

Methods: Data collection methods include questionnaires and interviews. This study uses primary data obtained through direct respondents. The statistical analysis tool in this study uses SPSS.

Results: Based on the results of data analysis and discussion, it shows that the knowledge variable has a positive effect on the motivation to implement green manufacturing. In addition, the second variable, namely regulation, also shows a positive effect on the motivation to implement green manufacturing. However, the third variable shows that costs have a negative effect on the motivation to implement green manufacturing.

Conclusion and suggestion: The results of the analysis prove that the tempe business motivation in Ngawi on implementing green manufacturing tends to be low. This requires synergy between the government and tempe entrepreneurs to applicate the green manufacturing. For the government, there is a need some socialization regarding the application of green manufacturing so that your knowledge of the application of green manufacturing will increase.
\end{abstract}




\section{INTRODUCTION}

During the economic crisis in 1997, Small and Medium Enterprises (SMEs) in Indonesia had proven their resilience. SMEs had made a very large contribution, which was in times of economic crisis large-scale companies were collapsed, followed by layoffs, but on the other hand SMEs were still able to run. Ngawi Regency is one of the districts in East Java Province that has many small and medium industries. In Sadang, Karang Tengan Prandon Village, there are many SMEs that have potential to be developed, such as batik, tempe, cassava rice, red and white rice, also tempe chips.The determination to spur job growth and increase people's purchasing power can be done by eliminating various factors that obstruct the growth of SMEs and development of existing small businesses, so that small businesses can play a role as national assets.

From this current development of the era also there is a link between regulations, knowledge, costs, natural resources (SDA) and technology that supports a job. Positive and negative impacts will certainly arise from the development of this industry, where the positive impact is the advancement on country's economy, while the negative impact is the emergence of waste and increase of pollution produced. Those problems are an impact that can damage the earth's ecosystem. In this case, we need a solution for those problems in the industrial world which will be useful for the next development. The movement is called green manufacturing.

The green manufacturing concept is a system of manufacturing that environmentally friendly. Green manufacturing involves transforming industrial operations in three ways, namely using green or environmentally friendly energy, developing and selling green or environmentally friendly products, and using green or environmentally friendly processes in its business operations (Green Manufacturing, 2011). The green manufacturing concept became very popular after being discussed in study conducted by the OECD (The Organization for Economic Co-operation and Development).

According to Hall et al. (2010), in its operation of sustainable development, it can be said that green manufacturing is inseparable from environmental, economic and social factors which is commonly referred to the triple bottom line. Environmental factors relate to the way companies use natural resources and waste treatment so that they have an impact on natural sustainability. Economic factors relate to the company's ability to generate maximum profit regardless of environmental and social factors. Social factors relate to the company's responsibility towards society.

Many demands from the government and society to pay more attention to the environment in every activity carried out by companies and industries, so they must think more about how to become greener companies or in other words environmentally friendly. This is evidenced by the existence of regulations about environmental 
protection and enviromental management, namely The Republic of Indonesia Law number 32 of 2009. In this regulation, it shows that we must be responsible not only for the society, but also for the environment around us. This regulation does not only refer to a particular industry, but to all industries in Indonesia. Companies that implement green manufacturing are companies which already pay attention to the environment, in other words, these companies will try to minimize industrial waste. Minimizing the waste can be done by reusing, reducing, and recycling. By minimizing waste, the company has automatically made savings and gets more benefits from the savings (Soedarmadji et al., 2015).

The Organization for Economic Corporation and Development (OECD) is an organization that discusses green manufacturing. According to the OECD, there are 3 categories of green manufacturing levels, they are the beginner, intermediate, and advanced levels. The determination of this level was based on the 18 indicators proposed by the OECD (2011). Green manufacturing operations range from developing product to managing product lifecycle involving environmental practices such as environmental design, clean production, recycling and reuse with a focus on minimizing costs associated with manufacturing, distribution, use and disposal of products (Lai and Wong, 2012).

Study conducted by Jovane et al. (2003) stated as a future paradigm with a business model based on design for the environment using nano / bio / new material technologies. They highlighted that the new paradigm will respond customers on needing more environmental friendly products. In addition, Wang and Lin (2007) proposed a broad triple bottom line framework for tracking and categorizing sustainability information at the company level through a sustainability index system. The framework incorporates costs, environmental and social values into the economic activities to support management decisions. Their methodology provides advice to help make decisions for making green manufacturing. Study conducted by Burke and Gaughran (2007) also presented another framework for realizing green manufacture. The framework is based on their study of SME producers achieving ISO 14001 certification.

Gomes and Shian (2012) in their study agreed that there is an increasing number of environmental friendly practices from manufacturing institutions in response to a very competitive market. Ratnasingam et al. (2008) added that more export-oriented manufacturing companies show much higher level of green manufacturing. This is approved by study conducted by Jegatheswaran Ratnasingam and Wagner (2009) in Malaysia which stated only 54 percent of respondents practice some green manufacturing and only 8 percent adopt the ISO 14000 environmental quality 
management system. This is also supported by Communities (2009) which stated designing for the use of non toxic materials, sustainably produced or recycled in a process are some of the general principles of environmental friendly design.

Moreover Callenbach et al. (1993) stated that technical and management skills of employees are a prerequisite for developing innovation-focused on environmental initiatives and programs. Thus, consistent inspiration of employees is necessary to produce significant managerial implications. In addition, independent departments need to be formed to ensure the smooth operation of the green manufacturing practices adopted by Lee (2008). On the other hand, study conducted by Noci and Verganti (1999) showed that the combination of corporate innovation with technological capabilities will pursue greater advances in green manufacturing practices.

Environmental problems are rooted from human activities as well as patterns of human consumption and production, so human care is needed, especially society, in maintaining environmental quality. The behavior of maintaining the quality of the environment is highly dependent on the level of knowledge, attitudes, and values that exist in consumers as human beings Mansaray \& Abijoye(1998); Chen \& Chai (2010); Said (2003) in Hutomo (2018). These business practices can cause environmental degradation that can threaten the prosperity and competitiveness of developing countries' economies (Schmidheiny, 1992). Environmental pollution is not only caused by companies in Indonesia, global manufacturing networks also pose significant risks to individual health and safety, national economies, and environmental impacts in local, regional and global scope (Rourke, 2005).

From the explanation about green manufacturing that has described above, it can be seen that the implementation of green manufacturing has indeed been partially implemented. However, its implementation is not easy for various reasons and it has not had a significant impact on the industrial world from several sectors, especially in developing countries, which have not maximally applied this concept particularly in terms of knowledge of green manufacturing. Studies on green manufacturing in Indonesia has not been done much, especially in relation of how to increase the knowledge of all industries about green manufacturing and how existing environmental standards or regulations can be maximally applied in Indonesia also the costs required on implementing green manufacturing are quite high. This study will combine a combination of knowledge, regulation, and cost variables which are expected to support the values of the maximum application of green manufacturing.

\section{LITERATURE REVIEW}

The influence of knowledge on the application of green manufacturing 
Industry awareness outside and within the country is based on the understanding that implementing green industry concepts in a sustainable manner can result the increasing in business margins and business competitiveness. The concept of the green industry includes the selection and substitution of materials and energy towards more efficient use without reducing product quality, becoming green products as planned. Reengineering of production processes and production technology is carried out continuously. With this understanding, the definition of green industry includes various activities from product design, material use, energy source use, machine selection, process design (location, layout, work system design), production processes, product handling (main, side, waste), to the distribution or product logistics.

Chen (2013) showed that environmental knowledge is a series of ecological knowledge that individuals have about the environment. Knowledge about the environment can affect consumer attitudes. The higher of knowledge level and environmental attention possessed by a consumer, the higher the ecological attitude of the consumer compared to consumers who do not have knowledge and concern for the environment which in turn affects their ecological behavior (Rini et al., 2017).

According to Sumarsono and Giyatno (2012) in in Rini et al. (2017), environmental attitudes are general tendency that occurs in a person and is formed or learned when responding consistently/ surely to environmental conditions in the form of like (positive) or dislike (negative) based on three things, namely: perception and knowledge about problems from the environment (a cognitive component), feelings or emotions that arise in the environment (an affective component), and the tendency to behave or act on the environment (a conative component).

On the other hand, (Chen, 2013) stated that environmental knowledge is a series of ecological knowledge that individuals have about the environment. The better the environmental knowledge possessed by consumers, the more knowledgeable the consumer will be about the quality of environmental friendly products. The higher the knowledge, the higher the motivation on applicating green manufacturing. Based on the results of the studies above, the following hypothesis can be taken:

\section{H1: Knowledge has a positive effect on the application of green manufacturing motivation.}

\section{The effect of regulation on the application of green manufacturing}

There are many different perspectives on environmental conservation issued by industry, as a result the definition of green industry also varies. To renew the concepts of industry, the Ministry of Industry proposed a Draft Law (RUU) which in it define the "Green Industry is an industry which in its production process prioritizes efficiency and effectiveness the use of resources in a sustainable manner so that able to harmonize 
industrial development with the preservation of environmental functions also can provide benefits to the society " As an operational follow-up, the Ministry of Industry drafted a green industry concept in Permenperind No. 05 / M-IND / PER / 1/2011 where the green industry is defined as an environmental friendly industry that harmonizes growth with environmental sustainability, prioritizes efficiency and effectiveness the use of natural resources and benefits the society.

In a comprehensive sense for the long term, the definition of a green industry as proposed in the Draft Law on Industry is appropriate, namely the deepening of industrial structure efficiency and effectiveness in the Implementation of Green Industry 23. Green industry is an industry which in its production process prioritizes efficiency and effectiveness the use of resources in a sustainable manner so that capable harmonizing industrial development with the preservation of environmental functions and providing benefits to the society. Operationally, each industry can compile its own definition. However, in order to be in line with the spirit of the Draft Law on Industry, at least the definition should include prioritizing the use of renewable resources, and using a series of efficient and effective production processes, both of which are aimed to participate in efforts to preserve environmental functions.

With this operational definition, to achieve a green industry, efforts towards green industry must be started from product design, use of materials, use of energy sources, machine selection, process design (location, layout), production processes, product handling (main, side, waste) and product distribution/ logistics. One of the limitation factors is the weak legal sanctions that apply in a country. The stricter the level of regulation, the higher the motivation for implementing Green Manufacturing. Based on the results of the research above, the following hypothesis can be taken:

H2: Regulation has a positive effect on the application of green manufacturing. The effect of cost on the application of green manufacturing

What cost elements should be taken into account in life cycle costs or costs arising from the life cycle associated with the product, costs associated with raw materials, cycle costs associated with the production process or industrial system. Wang \& Lin (2007) proposed a broad triple bottom line framework for tracking and categorizing sustainability information at the company level through a sustainability index system. The framework incorporates costs, environmental and social values into economic activities to support management decisions. Their methodology provides advice to help making decisions on implementing green manufacturing. Based on the research results above, the following hypothesis can be taken:

H3: Cost has a negative effect on the application of green manufacturing. 


\section{RESEARCH METHODS}

This study uses quantitative with multiple regression analysis test. This study is conducted by surveying 100 tempeh business actors and the object of this study is a place for making or processing the staple food, namely tempeh in Sadang, Karang Tengah Prandon Village, Ngawi Regency. To obtain and measure responses from respondents, the author uses a Likert Scale (Likert Scale). The data obtained through questionnaires will be processed using multiple linear regression analysis with the help of SPSS.

\section{RESULT AND ANALYSIS}

Table 1

Multiple Regression Analysis Test Result

\begin{tabular}{|c|c|c|c|}
\hline Indepemdent Variable & Coefficient & t-count & p-value \\
\hline Constant & 2,204 & & \\
\hline Knowledge (K) & 0,337 & 4,241 & 0.000 \\
\hline Regulation (R) & 0,319 & 3,500 & 0,001 \\
\hline Costs (C) & $-0,321$ & $-3,145$ & 0,002 \\
\hline F-count & & 39,496 & \\
\hline Sig- $F$ & & 0.000 & \\
\hline $\mathrm{R}$ & & 0,787 & \\
\hline Adjusted $R^{2}$ & & 0,603 & \\
\hline
\end{tabular}

Source: Data from regression

\section{The Effect of Knowledge on the Motivation of Green Manufacturing Implementation}

The result of testing the first hypothesis $(\mathrm{H} 1)$ shows that knowledge has a positive effect on the motivation to implement green manufacturing. So that the higher and more positive individual knowledge on green manufacturing will increase the motivation to implement green manufacturing. The result of this study is consistent with study conducted by Julina (2013) and Chen, T. B. and Chai L. T (2010). From this study, it can be concluded that knowledge of the environment can affect individual attitudes. By the higher the level of knowledge and environmental attention possessed by a consumer, the higher the ecological attitude of the consumer compared to consumers who do not have knowledge and concern for the environment which in turn affect their ecological behavior. Environmental knowledge is a set of ecological knowledge possessed by individuals regarding the environment. The better the environmental knowledge possessed by consumers, the more knowledgeable the consumer will be about the quality of environmental friendly products.

The Effect of Regulation on the Motivation of Green Manufacturing Implementation

The result of testing the second hypothesis $(\mathrm{H} 2)$ shows that regulation has a positive effect 
on the motivation to implement green manufacturing. So that the higher and more positive the regulations applied to green manufacturing will increase the motivation to implement it. The result of this study is in line with the research conducted by Wiengarten et al. (2012) and Priyono (2007). From this study it can be concluded that international policies regarding issues concerning the environment and energy saving are increasingly tightened through the international standard ISO14000 certification and eco-labeling program. Industry challenges are increased by the growing individual awareness of environmental issues that demand companies to implement environmental friendly regulations, such as eco-labeling, SFI (Sustainable Forestry Initiative) and FSC (Forest Steward Council) which have been implemented by the European Union.

\section{The Effect of Cost on the Motivation for Green Manufacturing Implementation}

The result of testing the third hypothesis (H3) shows that costs have a negative effect on the motivation to implement green manufacturing. So that the higher and more positive the use of green manufacturing costs, the less motivation to implement green manufacturing. This result is consistent with the study of Zhu and Sarkis (2004) and Frondel et al. (2007). From these studies it can be concluded that the adoption of this green color can cut costs, reduce processing and waste disposal costs, avoid fines in cases of environmental accidents also eco-innovation shows the positive role played by cost savings as a motivation for clean production technologies in particular.

\section{CONCLUSION}

The results of the analysis prove that the tempeh business motivation in Ngawi to implement green manufacturing tends to be low. This requires synergy between the government and tempeh entrepreneurs for the application of green manufacturing. For the government, there is a need for socialization regarding the application of green manufacturing so that the knowledge of entrepreneurs regarding the application of green manufacturing can increase. In addition, strengthening regulations must also be increased. This regulation is useful for providing rules regarding green manufacturing procedures and the financing process for green manufacturing. Further research is suggested to explore and analyze further about the factors that influence the motivation to implement green marketing by using other independent variables and other types of business.

\section{REFERENCES}

Burke, S., \& Gaughran, W. F. (2007). Developing a framework for sustainability management in engineering SMEs. Robotics and Computer-Integrated Manufacturing, 23(6), 696-703. https://doi.org/10.1016/j.rcim.2007.02.001

Callenbach, E., Capra, F., Goldman, L., Lutz, R., \& Hardback, S. M. (1993). EcoManagement: The Elmwood guide to ecological auditing and sustainable 
business. In Berrett-Koehler Publishers. 
Chen, Y. (2013). Economic implications of reducing carbon emissions from energy use and industrial processes in Brazil. Journal of Environmental Management, 130, 436446. https://doi.org/10.1016/j.jenvman.2013.08.049

Frondel, M., Horbach, J. and Rennings, K. (2007). End-of-pipe or cleaner production? An empirical comparison of environmental innovation decisions across OECD countries. Business Strategy and the Environment $16,8,571584$.

Gomes, M. and Y. L. Shian (2012). Dr. Jegatheswaran Ratnasingam on Green Technology in Furniture Manufacturing. Furnish Now. Kuala Lumpur, Media MICE Pte. Ltd.

Hall, J. K., Daneke, G. A., \& Lenox, M. J. (2010). Sustainable development and entrepreneurship: Past contributions and future directions. Journal of Business Venturing, 25(5), 439-448. https://doi.org/10.1016/j.jbusvent.2010.01.002

Hutomo, S. (2018). ANALISIS PENGARUH PERSEPSI PADA PRODUK MAKANAN ORGANIK TERHADAP NIAT UNTUK MELAKUKAN PEMBELIAN. Skripsi. http://awsassets.wwfnz.panda.org/downloads/earth_summit_2012_v3.pdf\%0Ahttp ://hdl.handle.net/10239/131\%0Ahttps://www.uam.es/gruposinv/meva/publicacion es jesus/capitulos_espanyol_jesus/2005_motivacion para el aprendizaje Perspectiva alumnos.pdf\%0Ahttps://www.re

Jovane, F., Koren, Y., \& Boër, C. R. (2003). Present and future of flexible automation: Towards new paradigms. CIRP Annals - Manufacturing Technology, 52(2), 543-560. https://doi.org/10.1016/S0007-8506(07)60203-0

Lai, K. hung, \& Wong, C. W. Y. (2012). Green logistics management and performance: Some empirical evidence from Chinese manufacturing exporters. Omega, 40(3), 267-282. https://doi.org/10.1016/j.omega.2011.07.002

Noci, G., \& Verganti, R. (1999). Managing "green" product innovation in small firms. $R$ and D Management, 29(1), 3-15. https://doi.org/10.1111/1467-9310.00112

Priyono, A. (2007). Pengaruh praktek green supply chain management terhadap kinerja perusahaan dengan peraturan pemerintah sebagai variabel moderasi. Jurnal Aplikasi Bisnis, 8(1), 1-12.

Ratnasingam, J., MacPherson, T. H., \& loras, F. (2008). An assessment ofMalaysian wooden furnituremanufacturers' readiness to embrace chain ofcustody(COC) certification. Holz Roh Werkst, 66, 339-343. https://doi.org/10.1007/s00107-0080255-3

Ratnasingam, Jegatheswaran, \& Wagner, K. (2009). Green manufacturing practices among wooden furniture manufacturers in Malaysia. European Journal of Wood and Wood Products, 67(4), 485-486. https://doi.org/10.1007/s00107-009-0341-1

Rini, A. S., Sukaatmadja, I. P. G., \& Giantari, I. G. A. K. (2017). Pengaruh Pengetahuan Lingkungan Dan Kepedulian Lingkungan Terhadap Sikap Dan Niat Beli Produk Hijau "the Body Shop" Di Kota Denpasar. E-Jurnal Ekonomi Dan Bisnis Universitas Udayana, 6(1), 137-166.

Rourke, T. W. O. (2005). Promoting School Health-An. 75(3).

Schmidheiny, S. (1992) Changing Course: A Global Business Perspective on Development and the Environment. MIT Press, Cambridge.

Soedarmadji, W., Surachman, S., \& Siswanto, E. (2015). Penerapan Konsep Green 
Manufacturing Pada Botol Minuman Kemasan Plastik. Journal of Engineering and Management Industial System, 3(2), 76-81. https://doi.org/10.21776/ub.jemis.2015.003.02.3

Wang, L., \& Lin, L. (2007). A methodological framework for the triple bottom line accounting and management of industry enterprises. International Journal of Production Research, 45(5), 1063-1088. https://doi.org/10.1080/00207540600635136

Wiengarten, F., Pagell, M., \& Fynes, B. (2012). Supply chain environmental investments in dynamic industries: Comparing investment and performance differences with static industries. International Journal of Production Economics, 135(2), 541-551. https://doi.org/10.1016/j.ijpe.2011.03.011

Zhu, Q., \& Sarkis, J. (2004). Relationships between operational practices and performance among early adopters of green supply chain management practices in Chinese manufacturing enterprises. Journal of Operations Management, 22(3), 265289. https://doi.org/10.1016/j.jom.2004.01.005 